\title{
An Application of Principal Component Analysis (PCA) using XRF data to delineate the continetality factor over beach sediments from Vengurla, West Coast, Sindhudurg district, Maharashtra, India
}

\author{
Praveen Gawali ${ }^{\mathrm{a}, \mathrm{b}, *}$, Satish Sangode ${ }^{\mathrm{b}}$, Milind Herlekar ${ }^{\mathrm{b}}$, Prafull Kamble ${ }^{\mathrm{b}}$, \\ andian Institute of Geomagnetism, Navi Mumbai \\ ${ }^{b}$ Dept. of Geology, Savitribai Phule Pune University, Ganesh Khind, Pune \\ ${ }^{*}$ Corresponding and presenting author
}

\begin{abstract}
We present here a novel approach of PCA to delineate the oceanic versus continental influence during pre-, mid and post monsoon seasons (PRM, MON, POM) over beach sedimentation at Vengurla along the west coast of India in Sindhudurg district, Maharashtra.PCA conducted over the XRF elemental results from 2003-2004 indicate a factor loading F1 for 2003 depicting predominant 'oceanic detrital' process and F2 as 'continental weathering' process. F1 for 2004 indicated 'continental weathering' with subdued 'oceanic detrital' process. F1 for the MON 2003 indicate 'continental detrital' process, and F2 subdued 'continental weathering' process. F1 for 2004 reveals 'continental detrital' and F2 'continental weathering' process. The overwhelming impact of monsoon can be inferred from this correlation. F1 for 2003 and 2004 POM as well can be assigned to 'continental detrital' process, and F2 to subdued 'continental weathering' process. The geochemical changes at Vengurla are season dependent, wherein hinterland is drained by monsoonal precipitation. The factor loading approach on mineral magnetic and geochemical data thus presents a precise semiquantitative method to delineate the continental and oceanic influence on the beach placers.
\end{abstract}

Keywords: PCA, beach, oceanic, continental

\section{INTRODUCTION}

Surface samples collected at 6 arrays on the Vengurla beach were investigated using XRF analyses to categorize their composition to understand the nature of source lithology and the prevailing energy conditions on the beach by using major geochemical elements and factor analysis. The Vengurla beach is one of the important beaches of Sindhudurg district having an extent of almost $4.5 \mathrm{~km}$. The geochemical composition reflects the relative presence of heavy and light minerals.The samples were collected in three different seasons (Premonsoon, Monsoon and Postmonsoon) for a period of two years from 2003 to 2004. According to [1] the geochemical entities found on the beaches comes largely from basic volcanic constituting dense minerals. The objective of the present study is to understand continental and oceanic input to the beach under investigation.

\section{THE STUDY AREA}

Vengurla beach has a width ranging from 30 to $150 \mathrm{~m}$ and has a length of $4.5 \mathrm{~km}\left(15^{0} 44^{\prime}-15^{0} 52^{\prime} \mathrm{N}, 73^{0} 35^{\prime}-73^{\circ} 40^{\prime} \mathrm{E}\right.$; Fig. 1) situated at an elevation of $1 \mathrm{~m}$, which is microtidal and has semi-diurnal tides, waves are plunging of $\sim 1.0 \mathrm{~m}$ height with a wave period of 5-6 sec and multiple breakers. The rainfall is $300-470 \mathrm{~cm} / \mathrm{y}$.

The lithology (Fig. 2) around Vengurla beach consists of granites, banded haematitequartzites, amphibolites and schists of garnetiferous variety [2]. The beach lies close to the town of Vengurla having bold to moderate relief. On the east side of the beach are the lofty Sahyadri hills and some deep valleys that forms its hinterland. Vengurlahas a coastline that is rocky to its north, but not to the south. Karli River is seen to flow in east-west direction to the north of Vengurla beach. Two more rivulets are seen to debouch into the Arabian Sea at the north and south end of the Vengurlaport hill. In general, the drainage pattern around Vengurla and also the Konkan sector is genetically related to the tectonics which have structurally deformed the geological formations[3]. 
International Advanced Research Journal in Science, Engineering and Technology

Vol. 8, Issue 9, September 2021

DOI: $10.17148 /$ IARJSET.2021.8902

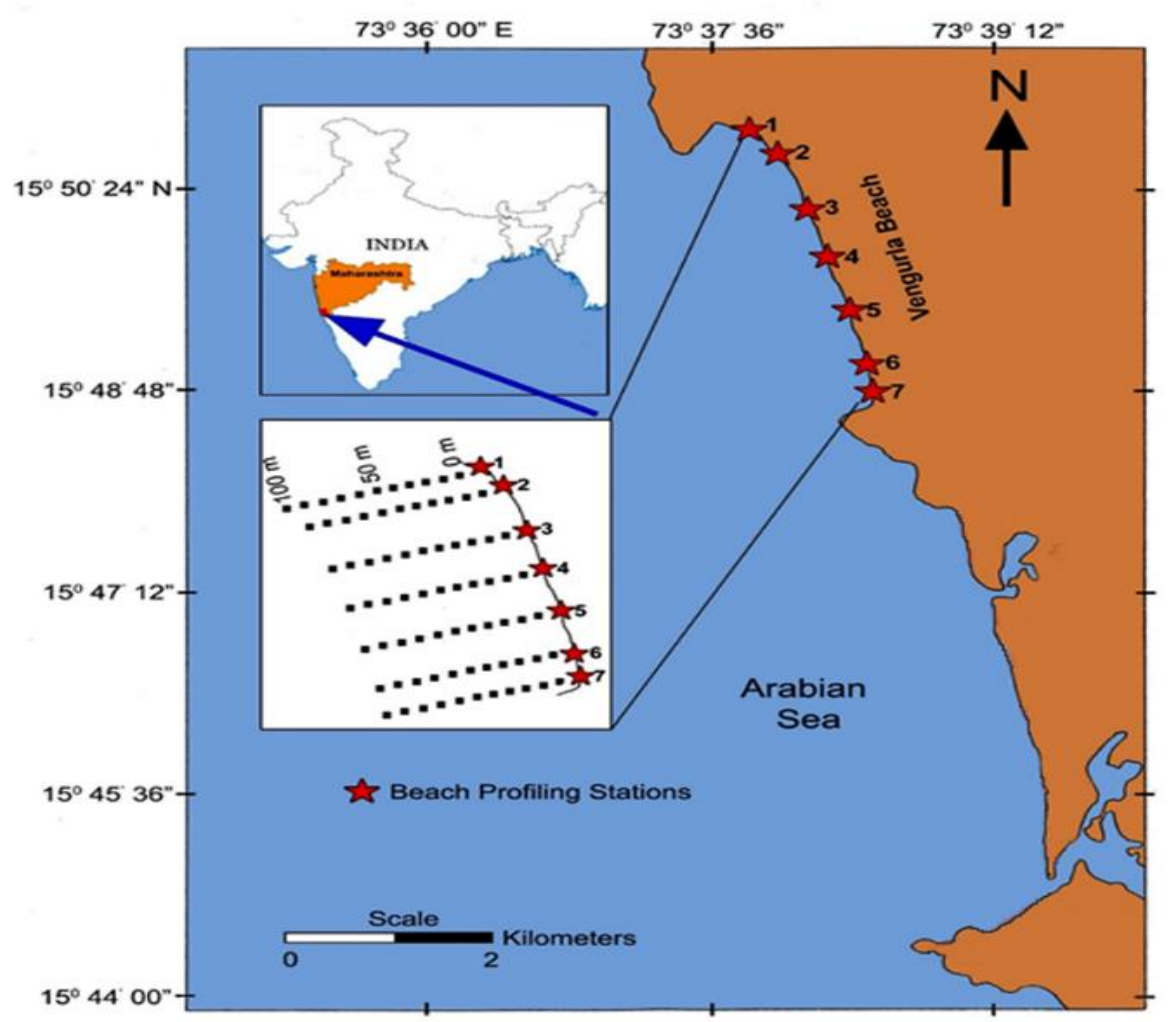

Fig. 1. Location map of the study area

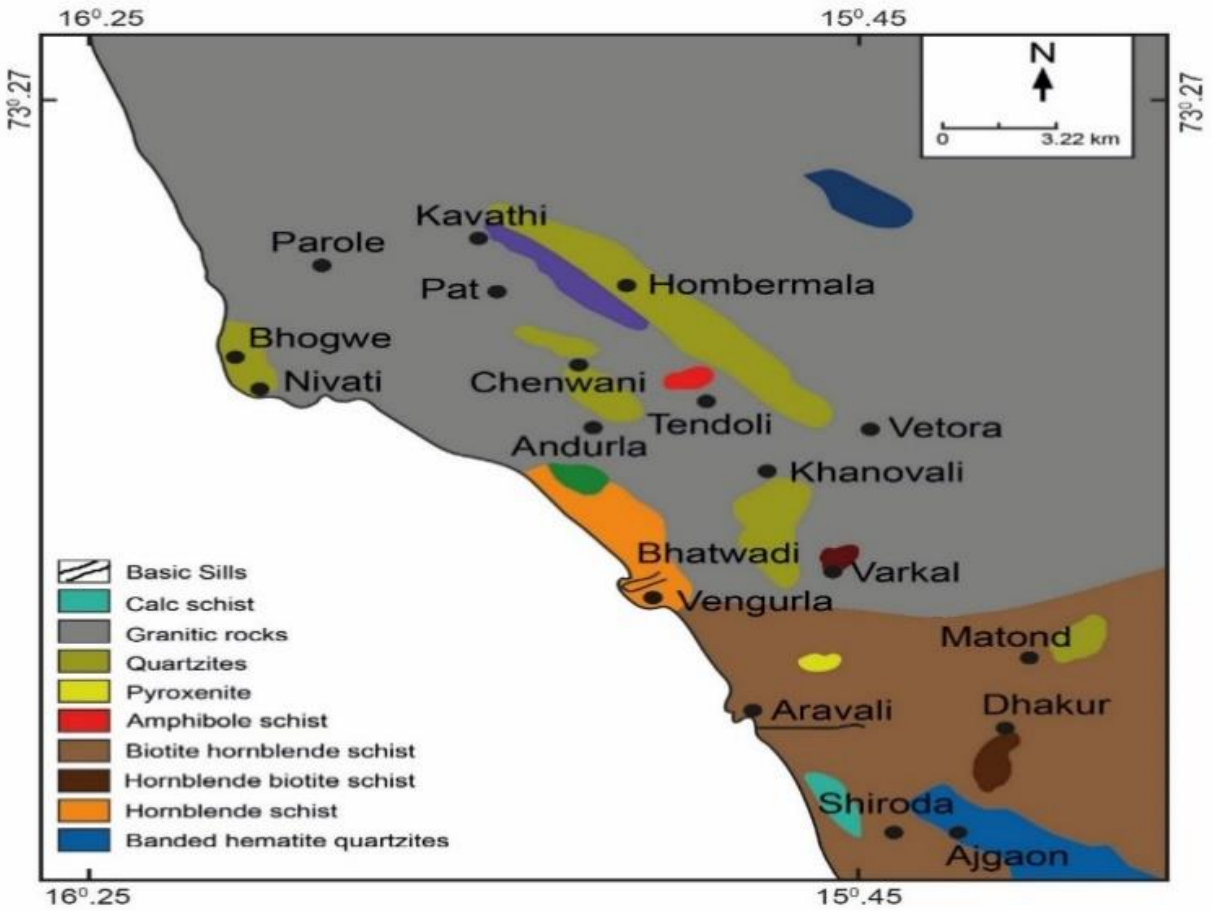

Fig. 2. Geology of the area around Vengurla (modified from [3].

\section{MATERIALS AND METHOD}

Surface samples were collected seasonally, as shown in Fig.1, at 6 arrays along the Vengurla beach and placed in polythene bags. They were oven dried in laboratory and prepared for geochemical analysis. First the samples were powdered and the pulverized for over 30 minutes using Fritsch Pulverisette, of Fritsch, France having planetary mono- 
mill. For analysis, sample was packed weighing about $3 \mathrm{~g}$ into plastic cups that have prolene $4 \mu \mathrm{m}$ thick membrane. In the present study 'Turboquant Powder' method was used. In this method samples are irradiated with X-rays emitted from the target material, wherein measurements were done thrice on a single sample. These three readings were then averaged out and used for analysis. The sample were subjected to X-ray radiation for 16 minutes.

Principal Component analysis (PCA) was harnessed to understand factors contributing to concentration of elements to characterize provenance of the detrital sediments. This method trims down a large data set comprising many parameters without missing out on vital information. PCA is a variance oriented method in which the first couple of components explain all variability of the data. The first and second component is independent of each other. There can be as many principal components as variables. We have used Xlstat in the present attempt and the principal components are found by calculating the eigenvectors of the data correlation matrix.

\subsection{Geochemical Parameters}

\subsection{RESULTS AND DISCUSSION}

11 samples from 4 arrays of the Vengurla beach, collected in all the three seasons were used for geochemical analysis. The XRF results reveal presence of $\mathrm{Si}, \mathrm{Al}, \mathrm{Fe}, \mathrm{Mg}, \mathrm{Ca}, \mathrm{K}, \mathrm{Sr}, \mathrm{Mn}, \mathrm{Na}, \mathrm{S}, \mathrm{Cl}, \mathrm{Ti}, \mathrm{V}, \mathrm{Cr}, \mathrm{Zr}$, and $\mathrm{Ba}$ which have been used for PCA.
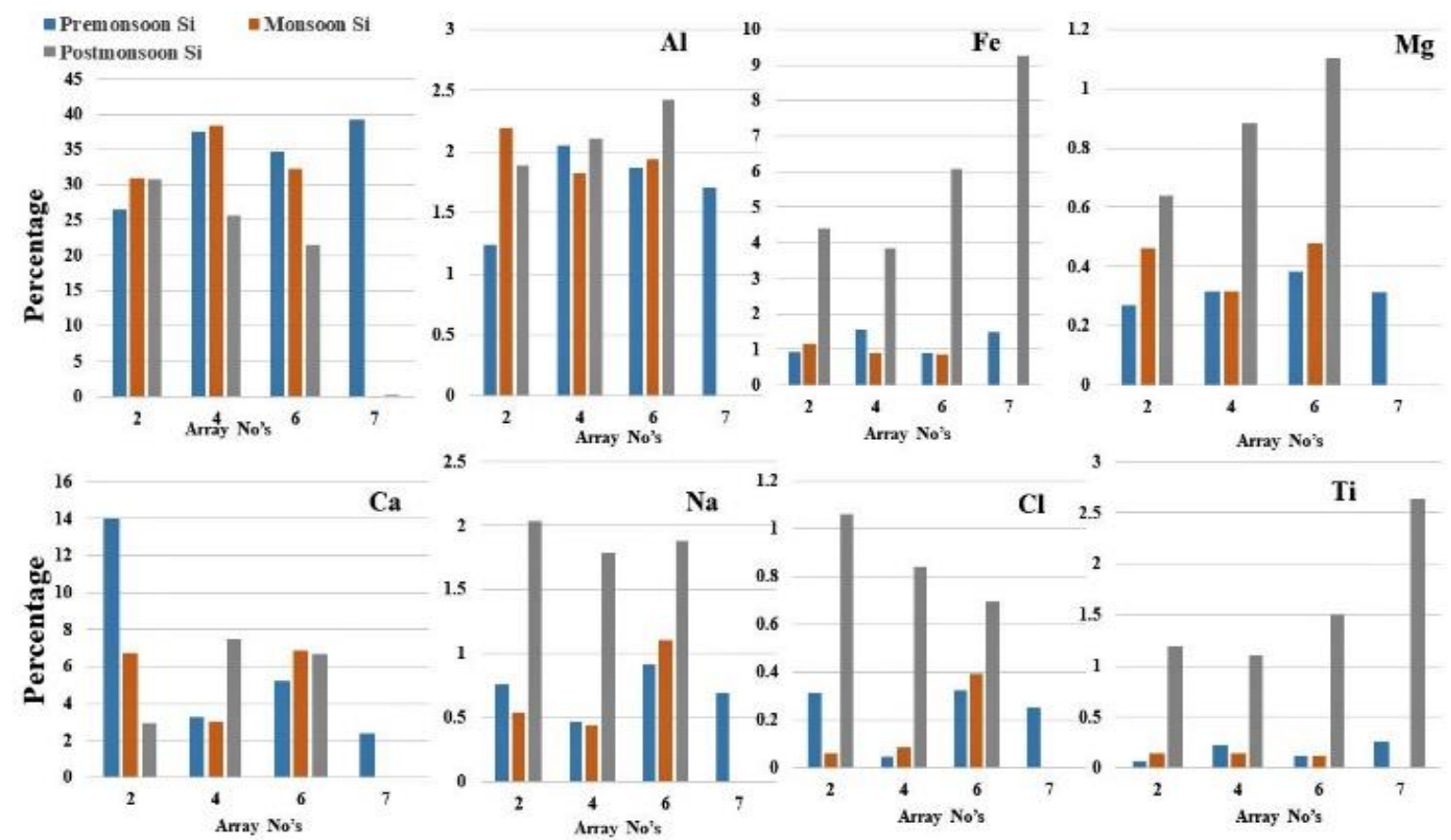

Fig.3. Seasonal variation of $\mathrm{Si}, \mathrm{Al}, \mathrm{Fe}, \mathrm{Mg}, \mathrm{Ca}, \mathrm{Na}, \mathrm{Cl}$ and Ti at arrays 2, 4, 6 and 7 of Vengurla beach in 2003

From Fig. 3 it can be seen that $\mathrm{Si}$ is seen to be more during MON at arrays 2 and 4, and at arrays 6 and 7 PRM. The concentration of $\mathrm{Al}$, is more at array 2 during MON; at arrays 4 and 7 PRM; and more POM at array 6. There seems to be some haphazardness in the distribution of this element throughout the seasons. With respect to arrays, Fe is more during MON at array 2, and more PRM at the rest of the arrays. Concentration of $\mathrm{Mg}$ is more during MON at array 2; POM at arrays 4 and 6; and marginally more PRM at array 7. This behaviour is similar to that of Al. Ca is more PRM at array 2, and POM at the rest of the arrays. $\mathrm{Na}$ is almost similar in concentration during MON and POM at array 2; increases at arrays 4 and $6 \mathrm{POM}$; and is more at array $7 \mathrm{PRM}$. $\mathrm{Cl}$ is more at arrays 2, 4 and $6 \mathrm{POM}$; and at $7 \mathrm{PRM}$. Ti is more during MON at array 2; and PRM at the rest of the arrays.

\subsection{Geochemical Parameters (2004)}

Geochemical analysis was carried on 10 samples from 4 arrays of the Vengurla beach, collected during all the three seasons. 


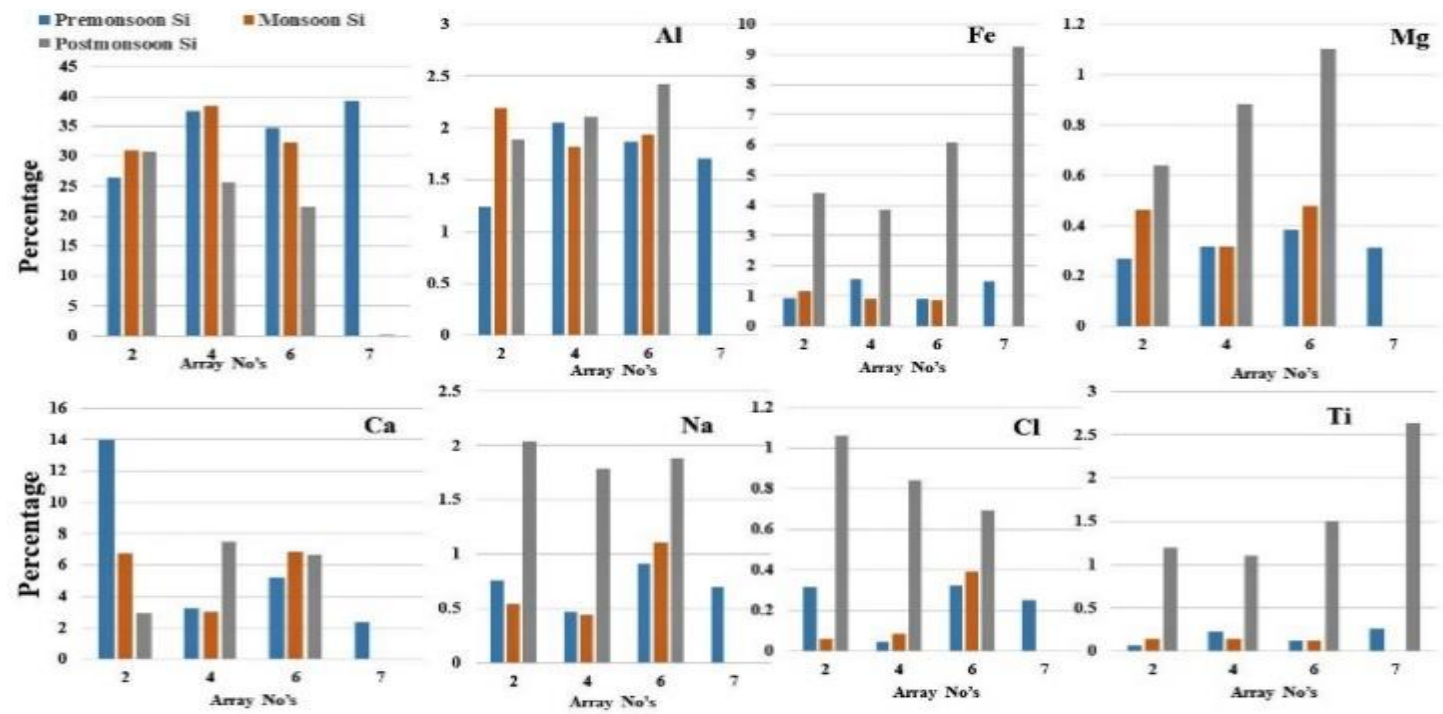

Fig.4. Seasonal variation of Si, $\mathrm{Al}, \mathrm{Fe}, \mathrm{Mg}, \mathrm{Ca}, \mathrm{Na}, \mathrm{Cl}$ and Ti at arrays 2, 4, 6 and 7 of Vengurla beach in 2004

From Fig. 4 it can be seen that $\mathrm{Si}$ is seen to be more during MON at arrays 2 and 4, and at arrays 6and 7 PRM. The concentration of $\mathrm{Al}$, is more at array 2 during $\mathrm{MON}$; at arrays 4 and $6 \mathrm{POM}$; and more PRM at array 7. Fe and $\mathrm{Mg}$ is more POM at all the arrays. Ca is more PRM at array 2, and POM at array 4, though it is more at array 6 in MON. $\mathrm{Na}, \mathrm{Cl}$ and $\mathrm{Ti}$ is more at arrays 2, 4 and 6POM.

Thus, from the foregoing it can be surmised that the beach-wide spread of different element variability changes with seasons. This change is heavily dependent on the mode of erosion and weathering, wherein the MON sees the dominance of precipitation and the seasons prior and post MON witness change in the medium through which the detrital grains are brought to the Vengurla beach.

\subsection{Principal Component Analysis}

The number of significant principal components was selected on the basis of Varimax orthogonal rotation with Kaiser Normalisation at eigenvalues greater than 1. From the principal component analysis following strong correlation patterns are seen to have formed: Na-Al-Cl; Mg-S-Ca-Sr; Si-Zr; Ti-Cr-Fe; and Mn-MS. Further, the factor loadings and communalities given in Table 1 reveal very interesting associations that can be related to the deposition/erosion processes carried by different agencies.

\begin{tabular}{|c|c|c|c|c|c|}
\hline & EI & E2 & 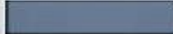 & FI & $\sqrt{12}$ \\
\hline $\mathbb{N a}$ & -0.775 & -0.473 & $\sqrt{\mathrm{Na}}$ & -0.684 & -0.633 \\
\hline $\mathrm{Mg}$ & 0.774 & -0.010 & $\mathrm{Mg}$ & 0.217 & -0.970 \\
\hline A I & 0.716 & -0.189 & $\overline{A I}$ & 0.794 & -0.489 \\
\hline Si & -0.900 & -0.070 & $\overline{s i}$ & 0.923 & -0.331 \\
\hline P & -0.020 & -0.986 & $\overline{\mathrm{P}}$ & 0.925 & 0.087 \\
\hline S & 0.478 & 0.000 & $\bar{s}$ & -0.963 & 0.271 \\
\hline CI & -0.843 & -0.364 & $\overline{\mathrm{CI}}$ & -0.792 & -0.330 \\
\hline$\underline{K}$ & -0.014 & 0.915 & $\bar{K}$ & -0.926 & 0.009 \\
\hline $\mathrm{Ca}$ & 0.945 & 0.153 & $\overline{\mathrm{Ca}}$ & -0.900 & 0.414 \\
\hline$\overline{\text { Ti }}$ & 0.725 & -0.679 & Tii & 0.963 & 0.052 \\
\hline $\mathrm{v}$ & 0.254 & -0.650 & $C_{r}$ & 0.860 & 0.369 \\
\hline$G_{r}$ & 0.492 & -0.869 & Mn & 0.752 & 0.657 \\
\hline Mn & 0.926 & -0.160 & $F_{0}$ & 0.935 & 0.349 \\
\hline $\mathrm{Fe}$ & 0.642 & -0.762 & $S_{T}$ & -0.898 & 0.418 \\
\hline $\mathrm{Sr}$ & 0.946 & 0.162 & $7 x$ & 0.650 & -0.717 \\
\hline $7 x$ & -0.838 & -0.340 & $\overline{\mathrm{Ba}}$ & -0.140 & -0.802 \\
\hline $\mathrm{Ba}$ & 0.538 & 0.841 & $\overline{M S}$ & 0.823 & 0.379 \\
\hline \multirow[t]{2}{*}{ MS } & 0.588 & -0.209 & & F1 & F2 \\
\hline & F1 & F2 & Eigenvalue & 11.110 & 4.218 \\
\hline Bigenvalue & 9.130 & 5.369 & Variability $(\%)$ & 65.352 & 24.815 \\
\hline $\begin{array}{l}\text { Varialitily }(\%) \\
\text { Cumblative } \%\end{array}$ & $\begin{array}{l}50.724 \\
50.724\end{array}$ & $\begin{array}{l}29.827 \\
80.550\end{array}$ & Camplative $\%$ & 65.352 & 90.167 \\
\hline
\end{tabular}

Table 1.Factor loadings and communalities associated with Vengurlapremonsoon 2003 (left) and 2004 (right) data 
The factor loadings and communalities associated with PRM 2003 Vengurla beach (Table 1, left) reveal F1 accounted for $51 \%$ variability and is mainly characterized by high levels of $\mathrm{Sr}, \mathrm{Ca}, \mathrm{Mn}, \mathrm{MS}, \mathrm{Mg}$ and $\mathrm{Ti}$. F2, on the other hand, accounted for $30 \%$ variance and is characterized by high levels of $\mathrm{K}$ and $\mathrm{Ba}$. The factor loadings and communalities (Table 1, right) associated with PRM 2004 Vengurla beach reveal F1 and F2 accounted for 65\% and 25\% variability respectively. $\mathrm{F} 1$ is characterized by the presence of $\mathrm{Al}, \mathrm{Si}, \mathrm{P}, \mathrm{Ti}, \mathrm{Cr}, \mathrm{Mn}, \mathrm{Fe}$ and $\mathrm{MS}$. No such strong presence is seen in F2.
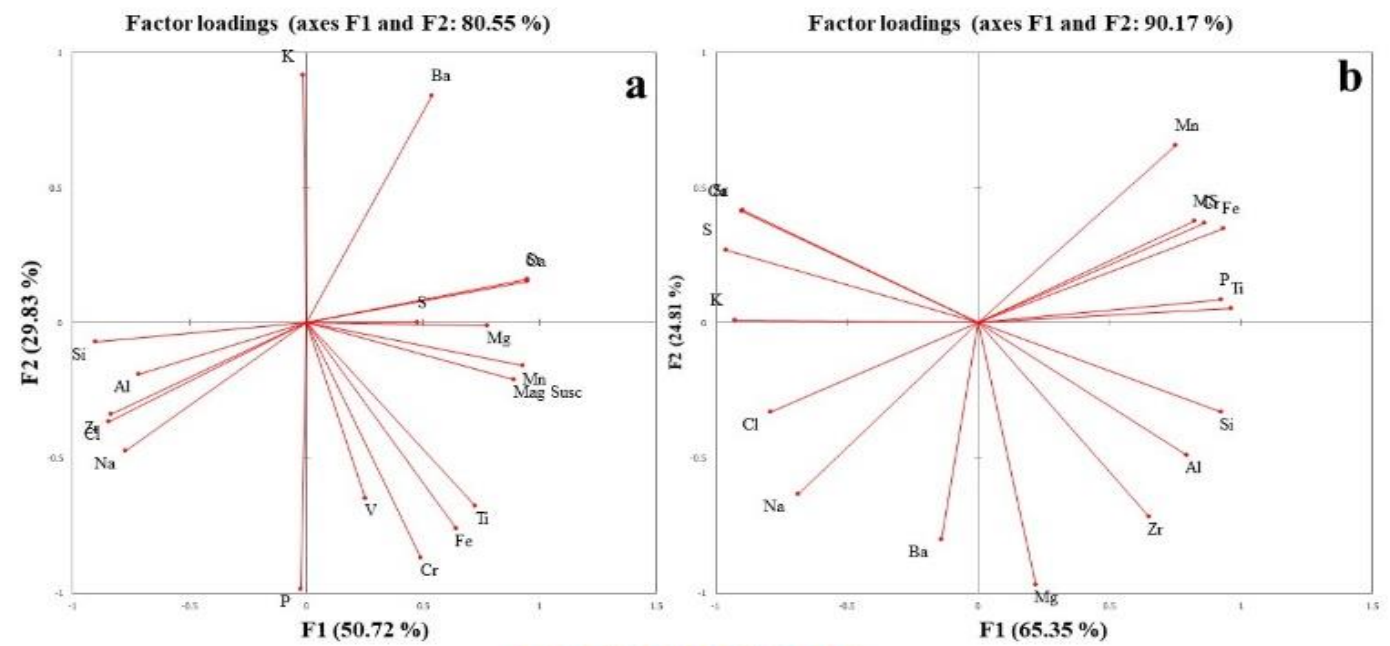

PREMONSOON

Fig. 5. The graphical representation of the factor loadings for PRM Vengurla 2003 (a) and 2004 (b) samples.

From the factor loadings seen in PRM 2003 and PRM 2004 (Fig. 5), F1 for 2003 can be assigned to 'oceanic detrital' process, and F2 to subdued 'continental weathering' process. This inference is based on the dominant presence of Sr, $\mathrm{Ca}, \mathrm{Mn}, \mathrm{MS}, \mathrm{Mg}$ and $\mathrm{Ti}$ as denoted by F1 in 2003. The continental weathering process is inferred to be represented by F2 because of the dominant $\mathrm{K}$ and Ba element assemblage. F1 for 2004, on the other hand, can be assigned to 'continental weathering' process along with a subdued 'oceanic detrital' process based on the dominance of continental detrital elements like $\mathrm{Si}, \mathrm{Al}$, Ti etc.

The PCA derived for MON 2003 revealed the following associations: Na-Mg-Al-P-Cl-Ti-Cr-Mn-Fe-Zr-MS; S-Sr; V$\mathrm{Cr}-\mathrm{Mn}-\mathrm{Fe}-\mathrm{Ba}$; $\mathrm{Cr}-\mathrm{Sr}-\mathrm{Zr}-\mathrm{Ba}-\mathrm{MS}$; Mn-Zr-Ba-MS. The factor loadings and communalities associated with MON Vengurla beach 2003 reveal $\mathrm{F} 1$ and $\mathrm{F} 2$ accounted for $85 \%$ and $15 \%$ variability revealing presence of $\mathrm{Na}, \mathrm{Mg}, \mathrm{Al}, \mathrm{P}$, $\mathrm{Cl}, \mathrm{Ti}, \mathrm{V}, \mathrm{Cr}, \mathrm{Mn}, \mathrm{Fe}, \mathrm{Zr}, \mathrm{Ba}$ and $\mathrm{MS}$; and $\mathrm{S}$ respectively. On the other hand, the PCA revealed strong correlation patterns to have formed in $2004 \mathrm{MON}$ as follows: Na-S-Cl-K-Ba; Mg-Ca-Sr; Al-Mn; P-Ti-Fe; Ca-Mn; Ti-Cr; Cr-Zr; $\mathrm{Sr}-\mathrm{Ba}$; Zr-MS. The factor loadings and communalities associated with 2004 MON reveal F1 accounted for $66 \%$ variability and is mainly characterized by high levels of $\mathrm{Na}, \mathrm{Mg}, \mathrm{S}, \mathrm{Cl}, \mathrm{K}, \mathrm{Ca}, \mathrm{Sr}$ and $\mathrm{Ba}$. F2, on the other hand, accounted for $34 \%$ variance and is characterized by high levels of $\mathrm{Al}, \mathrm{Mn}$ and $\mathrm{Fe}$.
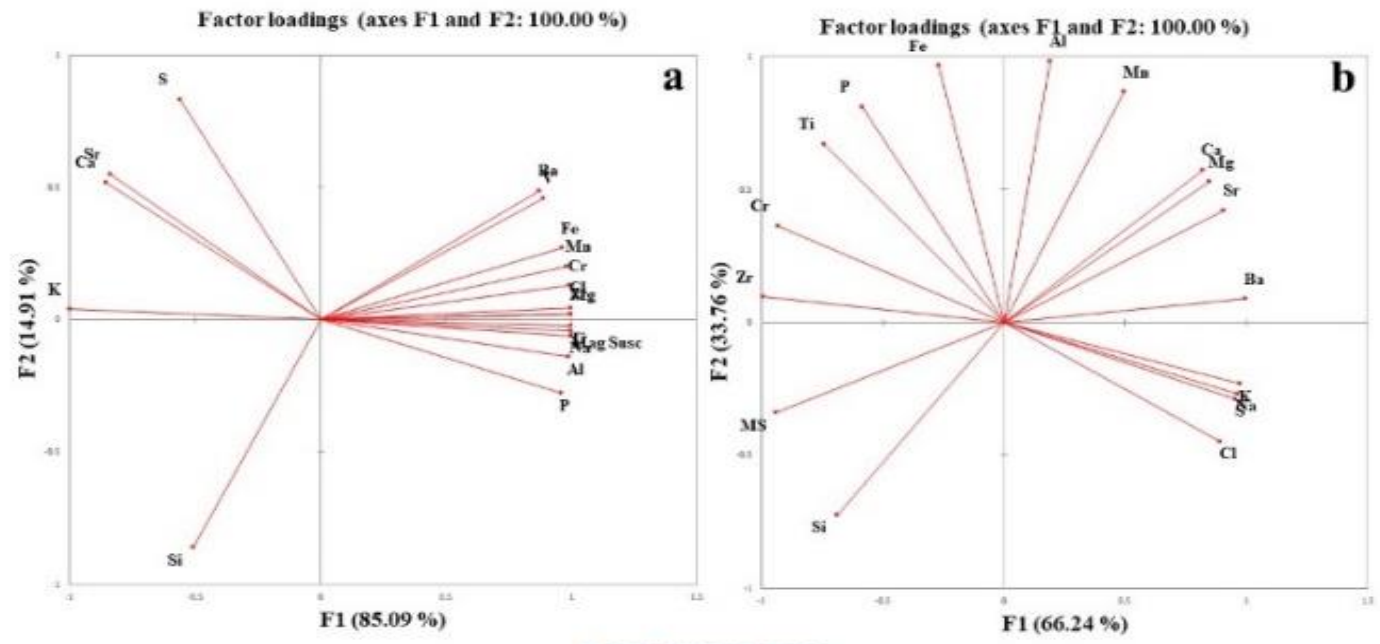

MONSOON

Fig. 6. The graphical representation of the factor loadings for monsoon Vengurla 2003 (a) and 2004 (b) samples.

(C) IARJSET This work is licensed under a Creative Commons Attribution 4.0 International License 
From the factor loadings (Fig. 6) seen in 2003 (a) and 2004 (b), F1 for MON 2003 can be assigned to 'continental detrital' process, and F2 to subdued 'continental weathering' process. F1 for 2004, can be assigned to 'continental detrital' process and F2 to 'continental weathering' process. The overwhelming impact of monsoon can be inferred from the correlation of diverse set of elements.

The PCA indicated strong correlation patterns formed POM 2003 at Vengurla beach as follows: Na-Si-Cl-Zr-MS; MgAl; Al-Ba; Si-P-Cr; P-Ti-Zr-MS; Ca-Sr; Mn-Ba. The factor loadings and communalities associated with 2003 POM reveal $\mathrm{F} 1$ accounted for $68 \%$ variability and is mainly characterized by high levels of $\mathrm{Na}, \mathrm{Mg}, \mathrm{Si}, \mathrm{P}, \mathrm{Cl}, \mathrm{Ti}, \mathrm{Cr}, \mathrm{Zr}, \mathrm{Ba}$ and MS. F2, on the other hand, accounted for $19 \%$ variance and is characterized by moderate levels of Al. In 2004 POM, the PCA displayed strong correlation patterns to exist between: Na-Al-Si-P-Cl-K; Mg-Al-P-S-Ca; S-Cl-K; K$\mathrm{Ba}$; Ti-Cr-Mn-Fe; Zr-Ba. The factor loadings and communalities associated with POM Vengurla beach 2004 reveal F1 and $\mathrm{F} 2$ accounted for $77 \%$ and $15 \%$ variability revealing presence of $\mathrm{Ti}, \mathrm{Cr}, \mathrm{Mn}$ and $\mathrm{Fe}$ for $\mathrm{F} 1$.
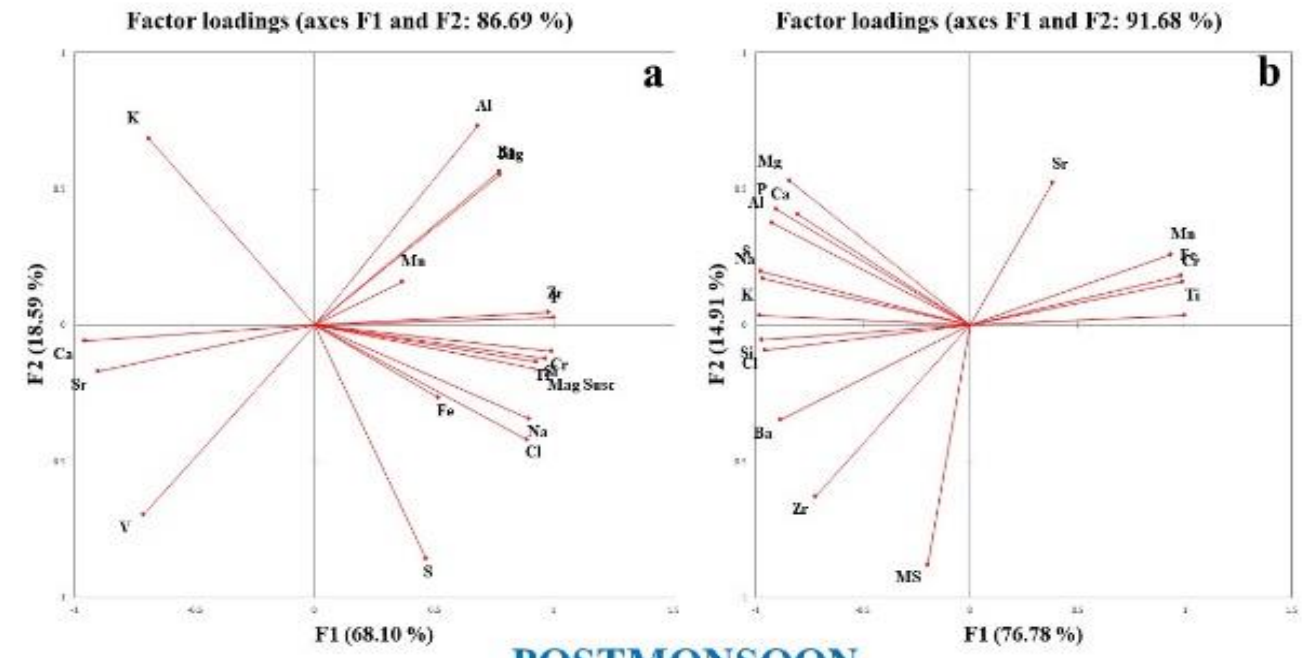

\section{POSTMONSOON}

Fig. 7. The graphical representation of the factor loadings are given below for POM Vengurla 2003 (a) and 2004

(b) samples.

From the factor loadings (Fig. 7) seen POM in 2003 (a) and 2004 (b), F1 for 2003 and 2004 as well can be assigned to 'continental detrital' process, and F2 to subdued 'continental weathering' process.

In 2003 at Vengurla a very strong correlation was found to exist between $\mathrm{Na}, \mathrm{Al}$ and $\mathrm{Cl} \mathrm{PRM}$; during MON it was between $\mathrm{Na}, \mathrm{Mg}, \mathrm{Al}, \mathrm{P}, \mathrm{Cl}, \mathrm{Ti}, \mathrm{Cr}, \mathrm{Fe}, \mathrm{Zr}$ and MS. POM strong correlation was seen to be limited to only between $\mathrm{Na}$, $\mathrm{Si}, \mathrm{Cl}, \mathrm{Zr}$ and MS. The average percentage of Si and $\mathrm{Ca}$ was more PRM in 2004; that of Al, $\mathrm{P}$ and $\mathrm{K}$ was in MON; whereas $\mathrm{Na}, \mathrm{Mg}, \mathrm{S}, \mathrm{Cl}, \mathrm{Ti}, \mathrm{Mn}$ and $\mathrm{Fe}$ was more POM. The changing seasonal pattern of geochemical signatures revealed different rates of erosion and deposition, which seems to be tied to the monsoonal precipitation in the area. Temporary change in drainage is discerned in both the years, through the addition of $\mathrm{P}, \mathrm{Mn}, \mathrm{V}$ and Ba to Vengurla beach sediments in MON, compared to PRM. Alternately, it also reveals the changing energy conditions and/or geochemical environment. There is seasonal variation in the kind and type of geochemical elements found. There is an increase in detrital elements during $\mathrm{MON}$, especially of $\mathrm{Si}, \mathrm{Al}$, and $\mathrm{Fe}$. The average percentage of $\mathrm{Na}, \mathrm{Mg}, \mathrm{S}, \mathrm{Cl}$ and $\mathrm{Ca}$ is more POM. Al, Si, K, Ti and Fe are seen to be more during MON. P and Ti percentage is relatively more PRM. In PRM 2003, the PCA reveals detrital input from the ocean was prominent, though continental weathering was an important process as well. In 2004 PRM, continental weathering was more prominent than oceanic weathering process. During 2003 and 2004 MON as well as POM continental detrital was found to be a primary process and continental weathering was a secondary process.

The geochemical changes at Vengurla are inferred to be season dependent wherein the hinterland seems to be drained vigorously by the monsoonal precipitation.

\subsection{Discussion}

The PCA on Vengurla beach sediments depicted significant oceanic influence during pre- monsoon interval of the year 2003, which appears to have reversed during in the year 2004. This can be related to changing intensity of monsoon, which was seen to have decreased in 2004 compared to 2003 (Table 4; [4]. 


\section{International Advanced Research Journal in Science, Engineering and Technology}

Vol. 8, Issue 9, September 2021

DOI: $10.17148 /$ IARJSET.2021.8902

\begin{tabular}{|l|l|l|l|l|l|l|l|l|l|l|l|l|}
\hline & Jan & Feb & Mar & Apr & May & Jun & Jul & Aug & Sep & Oct & Nov & Dec \\
\hline $\mathbf{2 0 0 3}$ & 8 & 4 & 0 & 0 & 0 & 7994 & 9656 & 4127 & 2659 & 173 & 47 & 0 \\
\hline $\mathbf{2 0 0 4}$ & 0 & 0 & 0 & 0 & 1189 & 6873 & 8552 & 7603 & 2277 & 324 & 110 & 0 \\
\hline
\end{tabular}

Table 4: The monthly rainfall data for the Konkan region denoted in $10^{\text {th }}$ of $\mathrm{mm}$

Table 4 reveals rainfall in 2004 was more in 2004 than 2003 except in the month of August 2004, signifying the detrital process is linked with the precipitational intensity of the area. The PCA also reveals the importance of considering the role of oceanic currents in context to understand the deposition/erosion pattern along the beach.

The geochemical changes at Vengurla are seasonal, wherein vigorous hinterland erosion can be discerned from Ba correlating well with $\mathrm{Mg}, \mathrm{Sr}$, and $\mathrm{Ca}$, since $\mathrm{Ba}$ has less mobility than $\mathrm{Mg}, \mathrm{Sr}$ and $\mathrm{Ca}[5]$. The low water level and breaker zones have high turbulence and energy [6][7] and the same can be seen at Vengurla. The placer formations at the beaches are a function of hydrodynamic processes [8], apart from cross-shore and shore-parallel sediment movement [9]. However, [10], consider swash zone processes define shoreline stability and beach morphology. The accumulation of heavy minerals is dependent on the provenance, though the geometry of shoreline and wave climate of the region is also seen to play an important role [11]. Grain size is dependent on provenance and its mineralogy, intensity of the currents [12] and incremental size decrease in the transport direction [13]. [14]carried morphological studies around Sindhudurg revealing accretion of beaches during postmonsoon and retrograding of beaches in the remaining two seasons. The addition or removal of detrital material to the beach is related to the type of waves, tides and longshore currents. One of the inference derived from the present study finds support in [15], who inferred concentration of placers at Vengurla is related to shoreline geometry and seasonality of wave climate. The sediments at Vengurla are inferred to move in northerly direction [16], though their movement can also be inferred to be northerly as well as southerly during 2004 premonsoon. The factor loadings revealed continental detrital process was primarily functional along with subdued continental weathering process at Vengurla beach.

\section{CONCLUSION}

The factor loadings revealed continental detrital process was primarily functional along with subdued continental weathering process at this beach during the 2003 and 2004 MON and POM periods. This study has wider implications on oceanic currents and continental detrital pathways.

\section{REFERENCES}

1. Marsaglia, K.M., 1993. Basaltic Island Sand Provenance, in Johnsson, M.J., and Basu, A., eds., Processes controlling the composition of clastic sediments: Geological Society of America Special Paper 284, p.41-65.

2. Deendar, D.I., 2003. Structural controls in the formation of iron ore deposits and laterite of Vengurla area. In: MEAI, Belgaum chapter workshop Souvenir "Sustainable Resource Management in Mining: With special reference in Coastal Regions of Karnataka and Maharashtra", 8-10.

3. Deendar, D.I., 2003. Structural controls in the formation of iron ore deposits and laterite of Vengurla area. In: MEAI, Belgaum chapter workshop Souvenir "Sustainable Resource Management in Mining: With special reference in Coastal Regions of Karnataka and Maharashtra", 8-10.

4. Kothawale, D.R., Rajeevan, M., 2017. Monthly, seasonal and annual rainfall time series for all-India, homogeneous regions and meteorological sub-divisions: 1871-2016. ISSN 0252-1075. A contribution from IITM Research Report No. RR-138, ESSO/IITM/STCVP/SR/02(2017)/189.

5. Das, A., Krishnaswami, S., 2007. Elemental geochemistry of river sediments from the Deccan Traps, India: implications to sources of elements and their mobility during basalt-water interaction. Chemical Geology 242, 232-254.

6. Bascom, W.N., 1951. The relationship between sand size and beach-face slope. Trans. AGU 32, 866. https://doi.org/10.1029/TR032i006p00866.

7. King, C.A.M., 1972. Beaches and coasts, 2nd ed. ed. Edward Arnold, London.

8. Kurian, N.P., Prakash, T.N., Jose, F., Black, K.P., 2001. Hydrodynamic Processes and Heavy Mineral Deposits of the Southwest Coast, India. Journal of Coastal Research 154-163.

9. Chandrasekar, N., Cherian, A., Rajamanickam, M., Rajamanickam, G.V., 2003. Formation of heavy minerals in the beaches between Kallar and Vembar. Current Science, 3(1), 207-212.

10. Li, L., Barry, D.A., Pattiaratchi, C.B., Masselink, G., 2002. BeachWin: modelling groundwater effects on swash sediment transport and beach profile changes. Environmental Modelling \& Software 17, 313-320.

11. Chandrasekar, N., Cherian, A., Paul, D.K., Rajamanickam, G.V., Loveson, V.J., 2005. Geospatial Application in the Study of Beach Placer along the Coast of Gulf of Mannar, India. Geocarto International 20, 69-74. https://doi.org/10.1080/10106040508542348

12. Chavadi, V.C., Hegde, V.S., 1989. A note on the textural variation of beach sediments in the vicinity of Gangavali river mouth near Ankola, west coast of India. Mahasagar, 22 (2), 89-97.

13. Pettijohn, F.J., 1975. Sedimentary Rocks. IInd edition, Harper and Row, New York, 718. (IIIrd edition: 628).

14. Hanamgond P. T., 2007. Morphodynamics of the beaches between Redi and Vengurla, Maharashtra, West Coast of India, Technical Report, Dept. of Science and Technology, Govt. of India (ESS/23/VES/138/2001).

15. Gawali, P.B., Basavaiah, N., Hanamgond, P.T., 2010. Mineral Magnetic Properties of Sediments of Beaches, Redi-Vengurla Coast, Central West Coast of India: A Seasonal Characterization and Provenance Study. Journal of Coastal Research 263, 569-579. https://doi.org/10.2112/081111.1

16. Hanamgond, P.T., Gawali, P.B., Lakshmi, B.V., Babu, J.L.V.M., Deendayalan, K., 2017. Sediment Texture and Geochemistry of Beaches between Redi-Vengurla, Sindhudurg, West Coast of India. JCR 33, 1135-1147. https://doi.org/10.2112/JCOASTRES-D-15-00194.1.

17. Shaziya Mohammed Irfan Momin. "Statistical Analysis of Physico-Chemical Parameters". International Research Journal on Advanced Science Hub, 2, 8, 2020, 118-122. doi: 10.47392/irjash.2020.104 